\title{
Tinjuan Teologi “Allah Kota Benteng” Dalam Mazmur 46:1-12
}

\author{
Desti Samarenna \\ Sekolah Tinggi Teologi Internasional Harvest Semarang \\ destisamarenna@gmail.com
}

\begin{abstract}
ABSTRAK
Tulisan ini, menguraikan tentang tinjauan teologi dari Mazmur 46 dan menjelaskan tentang kondisi Israel pada zamannya dan jawaban Allah secara teologi dan secara praktis. Mazmur ini adalah suatu penghiburan, namun penghiburan yang realistis. Hal tersebut dikarenakan Mazmur ini menceritakan tentang bagaimana keadaan dunia beritikad menghancurkan. Mazmur ini memiliki suatu nada yang optimis namun realisits. Mazmur ini menggambarkan dua prinsip yang saling bertentangan namun satu kesatuan (paradoks), yaitu Allah sebagai tempat perlindungan.
\end{abstract}

Kata Kunci: Perlindungan, Teologi

\section{PENDAHULUAN}

Judul kitab mazmur dalam Septuaginta memakai kata psalmos untuk menejrmahkan kata Ibrani Mizmor, istilah tehnis untuk satu kidung yang dinyanyikan dengan iringan instrumen. Naskah Yunani Alexandrinus dari Perjanjian Lama memberi judul Psalterion artinya alat musik yang memakai senar dan tali. Alkitab Ibrani memberi judul tehilim artinya puji-pujian. ${ }^{1}$

Seharusnya Allah menjadi gunung batu dalam realitas kehidupan orang percaya,namun hal tersebut masih menjadi konsep. Masih ada keyakinan yang belum tepat terhadap pribadi Allah. Karya dan pribadi Allah sering membuat orang percaya mudah menyerah dan menyatakan tidak sanggup menghadapi permasalahan yang sering datang dalam kehidupan mereka. Asumsi ini memang telah berakar dalam kehidupan orang percaya, dimana dijaman yang penuh dengan informasi ini jalan keluar dan pertolongan seringkali digantikan dengan jawaban ilmu pengetahuan modern atau nilai yang diberikan. Bergesernya "kebenaran," menjadi hanya sebuah pengetahuan

\footnotetext{
${ }^{1}$ Hassell Bullock, Kitab-kitab Puisi dalam Perjanjian Lama, pen., Suhadi Yeremia, peny., Sumarah (Malang: Gandum Mas, 2003), 152.

mengakibatkan cara pandang terhadap Allah berubah.

Pemahaman yang berbeda tentang Allah akan menghasilkan interpretasi serta refleksi iman yang berbeda.

Thiessen, menjelaskan "Allah itu transenden dan imanen, ia ada dimana-mana dalam hakikat maupun dalam pengetahuan dan kuasaNya. Kapan pun dan di mana pun zat rohani itu ada, maka seperti jiwa, pastilah ia utuh apa adanya...Sesungguhnya, Allah tidak terpahami..Allah mengetahui. Kasih tidak acuh tak acuh: Allah memperhatikan dan menolong. Kemahakuasaan bukanlah tidak berdaya: Allah bertindak. $^{2}$

Kehadiran Allah dan karyanya bukan hanya sebuah ide, konsep tetapi sungguh menjadi realita. Dalam kajian terhadap teks ini, penulis memberikan penjelasan tentang pemazmur yang secara langsung menyatakan kehadiran Allah dalam realita hidupnya. Masihkah Allah berintervensi sebagai gunung batu, ditengah-tengah situasi dan keadaan yang tidak ada jawabannya? Berikut penulis akan memaparkan pengalaman pemazmur bersamasama dengan Allah sebagai jawaban atas keadaan dan situasi yang dihadapi.

\footnotetext{
${ }^{2}$ Henry C. Thiessen, Teologi Sistematika (Malang: Yayasan Penerbit Gandum Mas, 1997), 118, 134-135.
}

Desti Samarena, Tinjauan Teologis... 


\section{METODE PENELITIAN}

Dalam menyajikan kajian ini maka jenis penelitian yang digunakan adalah penelitian deskriptif kualitatif. Jenis penelitian ini akan menghasilkan data-data yang akurat yang bersumber dari buku-buku yang dianalisis, eksegesis, dan eksposisi. Metode-metode yang digunakan dalam penyelesaian penelitian dituliskan di bagian ini.

\section{PEMBAHASAN}

Argumentasi terhadap hipotesa di atas akan diberikan pembuktian melalui tinjauan teologi terhadap Mazmur 46:1-12. Penekanan dari Mazmur ini menceritakan tentang Allah Israel yang perkasa. Pemazmur maenjelaskan keberadaan bangsa Israel yang sedang mendapat tantangan dari luar, di mana bani korah sebagai kelompok yang menyanyikan nyanyian ini, sekaligus kelompok yang menyanyikan nyanyian terhadap Mesias, yang memberi pertolongan dan kelepasan kepada mereka. Ada penegasan dan ekspresi iman Israel pada hari-hari gelap yang sedang menunggunya, namun pengepungan Yerusalem oleh Asyur pada pemerintahan Hizkiah memberikan penggambaran yang jelas terhadap hal tersebut. $^{3}$ Sehingga dalam memberikan penjelasan terhadap bagian Mazmur ini perlu melihatnya dari sisi latar belakang peristiwa sejarah yang terjadi sampai akhir Mazmur ini ditulis.

\section{Latar belakang Mazmur 46:1-12}

Diperkirakan ditulis seteah Sanhenrib menyerang Yerusalem (2Taw. 32). ${ }^{4}$ Peristiwa penyerangan terhadap Yerusalem kemungkinan merupakan latar belakang sejarah dari kitab ini, hanya saja ada beberapa sarjana yang meragukan latar belakang peristiwa ini, mereka mengatakan bahwa ada dua macam penafsiran yang bisa dipakai untuk nats ini, pendapat yang lebih tua mengaitkan mengenai kelepasan yang

\footnotetext{
${ }^{3}$ Leslie S M'Caw, "Mazmur" dalam Tafsiran Alkitab Masa Kini 2, pen., F. Ukur Jakarta: Yayasan Komunikasi Bina Kasih, 1996), 177.
}

tiba bersamaan dengan sebuan Sanherib (2Raj. 18; 2Taw. 32). Mazmur ini dengan upacara tahunan bait Suci, yang diduga ada saat dimana raja keturunan Daud itu dinyatakan dalam selengkap ketidak berdayaan insani dan sepenuhnya dikalahkan oleh kuasa-kuasa dunia ini, sampai Tuhan datang dan turut campur tangan dan melepaskan dia dengan cara menghancurkan musuh-musuhnya. Upacara yang sedemikian itu akan membantu tetap menyegarkan makna hakekat kerajaan dikalangan bangsa Israel. Kedua tafsiran diatas hanya merupakan dugaan dari para ahli sejarah yang masing-masing memiliki argumen untuk menguji kebenaran yang tersembunyi dibalik latar belakang Mazmur ini. Pendapat penafsiran pertama, diteliti dari usia tafsiran ini lebih tua dari tafsiran yang satu, penulis juga melihat adanya kesinambungan antara peristiwa yang dicatat dalam 2 Tawarikh 32 dengan mazmur yang dinyanyikan oleh bani Korah dalam pasal 46 ini. Dengan demikian, ada kemungkinan latar belakang mazmur 46 ini dapat ditentukan dalam kitab 2 Tawarikh pasal 32.

Dalam konteks 21 Tawarikh 32, dua kali Asyur memberikan opini tentang ketidakmampuan Allah Israel untuk menyelamatkan bangsa Israel, dengan berkata bahwa Allah takkan dapat melepaskan dari tangan Asyur $(15,17)$. Ungkapan tersebut bukan hanya mau mensejajarkan Allah Israel dengan para baal, tetapi lebih kepada merendahkan derajad dan kuasa dari Allah Israel. Hal ini berarti Allah sungguh-sungguh tidak dapat mengeluarkan Israel dari cengkraman Asyur, (dalam asumsi raja Asyur).

Inti dari intimidasi tersebut adalah untuk mempertanyakan apakah Tuhan akan menolong mereka, dan memberikan kesan buruk terhadap pemerintahan Hizkia, serta menuju kegagalan ilahi lokal untuk menyelamatkan Hamat dan Samaria. Tentu saja tuduhan yang diajukan terhadap Allah Israel merupakan tuduhan yang palsu, yang dari sisi sejarah serta aplikatif tidak dapat dibuktikan kebenarannya. Oleh sebab itu dalam bagian selanjutnya penulis memaparkan beberapa bentuk pertolongan Allah kepada bangsa Israel yang bersifat rohani. Artinya 
pertolongan Allah kepada bangsa Israel yang bersifat rohani, artinya pertolongan Allah yang diberikan kepada mereka dalam konteks ini memiliki indikasi untuk membangun serta menguatkan iman mereka kepada Allah.

Allah Israel adalah satu-satunya Allah yang dapat diandalkan dalam kondisi apapun. Inti dari semua tuduhan yang dilontarkan adlah untuk menentang Tuhan sekalgus juga menentang Hizkia hambaNya (ay. 16). Menghadapi serangan diplomasi politis dari raja Asyur tersebut ternyata tidak nenyurutkan semangat kepahlawanan dari raja Hizkia beserta bangsa Israel yang menyertainya di Yerusalem. Hal ini dapat dilihat langsung dengan pernyataan bani Korah yang disampaikan dalam bentuk mazmur iman, seperti yang terdapat dalam mazmur pasal 46.

\section{Pertolongan Allah Secara Teologis}

Pertolongan Allah secara teologs dalam teks ini adalah Allah sebagai tempat perlindungan, Allah sebagai Sumber Kekuatan, dan Allah sebagai Jaminan Keselamatan akan dijelaskan sebagai berikut:

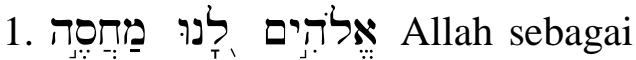
Tempat Perlindungan (Ay. 1-2)

Mazmur 46 ini termasuk dalam himne atau nyanyian pujian yang diawali dengan seruan untuk memuji Tuhan, diikuti dengan pujian itu sendiri, yang mengambil berbagai bentuk ekspresi. ${ }^{5}$ Dalam bagian awal Mazmurnya, bani korah menjelaskan bahwa Allah merupakan tempat perlindungan yang kokoh bagi mereka. Ungkapan tempat perlindungan berasal dari bahasa Ibrani hs,x.m; (Maheseh) yang memiliki pengertian kata tameng, benteng, pengungsian, proteksi diri, dan seperti payung atau tempat berteduh ketika hujan. Hal yang sama yang dapat dilihat dalam Yesaya 4:6, 25:4, dan Mazmur 108:18. Allah yang ditampilkan sebagai tempat perlindungan merupakan bagian dari

\footnotetext{
${ }^{5}$ Ibid., 184.

${ }^{6}$ Walter C. Kaiser, Teologi Perjanjian Lama

(Malang: Gandum Mas, 2000), 133.

${ }^{7}$ Kaiser, Teologi Perjanjian Lama, 133.
}

kedekatan mereka dengan Tuhan, bahkan pemazmur menunjukkan hal tersebut dengan berkata bahwa Allah itu bagi kita (ay. 2). Dari ungkapan tersebut pemazmur sedang mengakui tentang kebesaran Tuhan, sekaligus juga tentang kedekatan mereka dengan Allah sehingga mereka dapat memanggil Allah, yang kemudian dihubungkan dengan Yakub sebagai bapa leluhur mereka (ay. 9, 12).

Dalam bentuk yang sama Mazmur 91 juga memberikan penggambaran terhadap Tuhan yang merupakan tempat perlindungan. Dalam konteks yang sama, pribadi Allah ditampilkan sebagai Yang Mahatinggi atau Elyoan, serta Yang Mahakuasa atau Shadai (ay.1). ${ }^{6}$ Kata Shaddai dalam bagian ini memberikan penekanan pada pekerjaan adikodrati oleh kasih karunianNya, yang sekaligus juga menunjukkan kemampuan Allah untuk menguasai alam. ${ }^{7}$ Istilah shaddai mungkin berarti gunung, adalah lambang yang dipakai untuk menjelaskan kondisi ketidak berubahan dan kekuatan yang abadi, yang tentu saja berlawanan dengan kesementaraan dan ketidak berdayaan manusia. ${ }^{8}$ Dengan kata lain ungkapan Tuhan sebagai perlindungan pemazmur sedang mendeklarasikan keselamatan yang diperoleh dari Tuhan sebagai akibat dari sikap hidup beriman kepadaNya, yang senantiasa hadir untuk memberikan pertolongan kepada umat yang beriman dan berserah sepenuhnya kepada Allah, terlebih ketika mereka ada dalam bahasa yang mengancam keselamatan mereka. ${ }^{9} \mathrm{Hal}$ ini menunjukkan, sekalipun ditengah-tengah kegelapan dan ancaman yang dilakukan oleh musuh, orang percaya masih memiliki Allah yang adalah sumber kekuatan. Kekuatan yang tidak dapat tertandingi karena berkaitan erat dengan pribadinya yang adalah Allah.

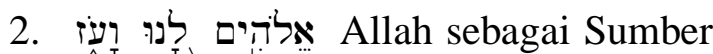
Kekuatan (Ay. 2)

Mengikuti ungkapan Allah sebagai tempat perlindungan, bani Korah sebagai penulis mazmur menyapa Allah sebagai sumber kekuatan. Ungakapan kekuatan dalam bahasa Ibrani disebut dengan i' secara arti kata dalam

\footnotetext{
${ }^{8}$ Alec Motyer, "Nama-nama Sebutan untuk Allah" dalam Pedoman Lwngkap Pendalaman Alkitab, 1978. ${ }^{9}$ John F. Walvoord, The Bible Knowledge Commentary (Grand Rapids: Victor Book, 1995), 825.
} 
bidang militer atau perlengkapan perang atau hikmat yang berkaitan dengan keteraturan, dalam hal ini diawali dengan kata penghubung dan (w), sehingga menjadi

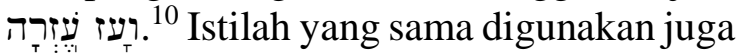
dalam Hakim-hakim 5:1, Yesaya 26:1. Artinya bani Korah sungguh-sungguh menyadari bahwa ditengah-tengah kegelapan dan ancaman yang sedang mereka hadapi, mereka masih memiliki Allah yag adalah kekuatan bagi mereka. Kekuatan yang tidak dapat tertandingi karena berkaitan erat dengan pribadinya yang adalah Allah, yang tentu saja berkaitan erat dengan aspek-aspek keilahianNya yang berkuasa. Implikasi hubungan yang dekat ini, pada nantinya akan nampak terlihat sepenuhnya ketika Allah hadir bersamasama dengan mereka (Yeh. 37:26-28). ${ }^{11}$

Bangsa Israael, sungguh-sungguh menikmati hubungannya dengan Tuhan, melalui pengenalan dan pengalaman mereka bersama-sama dengan Tuhan. Dalam kondisi ini mereka memperoleh keyakinan yang kokoh akan jaminan penyertaan, perlindungan dan adanya kekuatan yang berasal dari Tuhan, yang menyertai mereka dalam setiap pergumulan dan permasalahan hidup. Allah yang disembah oleh orang Israel dan orang percaya adalah Allah yang hidup, Allah yang turut merasakan apa yang dirasakan oleh manusia (Ibr. 4:15). Oleh sebab itu ketika orang percaya mengalami kesulitan, himpitan permasalahan dalam kehidupan ini, maka ia akan memberikan kekuatan dan memampukan untuk menghadapi setiap kesulitan tersebut.

3.Allah sebagai Jaminan Keselamatan (Ay. 3-4)

Dengan penuh perasaan yang kagum dan hormat kepada Allah, akhirnya bani Korah dengan menggunakan mazmurnya berkata bahwa Allah yang adalah tempat perlindungan dan kekuatan, merupakan

\footnotetext{
${ }^{10}$ Jhon Joseph Owens, Analitical Key to the Old Testament (Grand Rapids: Baker Book House, 1995), 336.

${ }^{11}$ William Dyrness, Tema-tema dalam Teologi Perjanjian Lama, 30.
}

penolong yang sejati ketika berada dalam kesesakan. Hal ini juga yang menjadi jaminan bagi mereka untuk tidak takut sekalipun bumi berubah, sekalipun gunung-gunung goncang didalam laut, sekalipun ribut dan berbuih airnya, sekalipun gunung-gunung goyang oleh gelorahnya (ay. 3-4). Istilah kesesakan yang digunakan dalam nyanyian bani korah adalah berasal dari bahsa Ibrani hr;c; (tsarah) yang memiliki arti literal sebagai "keadaan terjepit."12 Dalam konteks ini, penulis merasa bahwa bani Korah sedang menghubungkan hal tersebut dengan suatu peristiwa ketika mereka berada di belakang tembok pagar Yerusalem pada waktu Yerusalem dikepung.

Mazmur ini sebenarnya memberikan penjabaran kisah mengenai keberhasilan seseorang dalam menghadapi ketakutan. Pribadi ini sedang berada dalam bahaya yang besar dan bahaya ini dibandingkan dengan fenomena gejolak alam berupa laut yang bergelora, gempa bumi yang besar dan yang lainnya. Antara ayat 4 dan 5 ada kata 'sela' yang berarti semacam tanda baca. Dalam not itu ada nol, berarti tidak berhenti tidak dinyanyikan tetapi direnungkan. Pemazmur mengatakan bahwa sekalipun bumi berubah namun tidak akan takut karena bersama Allah tidak akan takut sekalipun realita di sekitar alam bergoncang. Jadi, konsep yang kuat terhadap Allah yang memberikan pertolongan, tempat perlindungan dan kekuatan memampukan mereka untuk tidak menjadi takut dalam dua hal sekaligus, baik itu terhadap kekacauan yang disebabkan oleh alam, maupun kekacauan yang disebabkan oleh musuh. Dengan demikian kesesakan yang sementara dialami oleh bangsa Israel dalam bagian ini dapat dipahami sebagai suatu kesesakan akibat permasalahan alam dan adanya intimidasi dari pihak musuh. ${ }^{13}$ Melalui jaminan tersebut di atas setidaknya umat pilihan Allah tidak perlu takut sekalipun ada begitu banyak bahaya dan permasalahan yang datang mengancam. Penggunaan bahasa yang hiperbolik tersebut dimaksudkan untuk menjadi sebuah tuntutan kepada Israel untuk tetap mempercayai Allah, dalam apapun kondisinya karena hanya dengan

\footnotetext{
12 Owen, Analitical Key

${ }^{13}$ John F. Walvoord, The Bible Knowledge Cpmmentary, 228. [terjelmahan langsung]
} 
iman kepada Allah maka tetap ada jaminan keselamatan yang dari Allah.

Seharusnya berdasarkan pengalaman hidup berjalan bersama Allah, menjadi alasan yang kuat bagi bangsa Israel dan orang percaya untuk menyakini bahwa Allah senantiasa menyertai mereka dalam segala situasi. Kehadiran dan perlindungan yang disertai dengan pertolongan Allah merupakan bukti nyata bahwa hanya berkat perlindungan dan keselamatan yang dari Allah saja mereka untuk dapat terus bertahan sekalipun berada ditengah-tengah intimidasi dari bangsa-bangsa lain. Pengalaman ini seharusnya menjadi iman mereka kepada Allah sebagai pribadi yang memberi perlindungan, kekuatan dan jaminan keselamatan semakin kuat dan kokoh. Kalau pada bagian sebelumnya penulis memberikan bukti-bukti pertolongan Allah secara rohani maka pada bagian berikut penulis akan memberikan penjelasan tentang pertolongan Allah yang bersifat praktis, artinya pertolongan Allah bukan hanya sekedar rohani untuk menguatkan iman mereka kepada Allah tetapi lebih condong pada pertolongan Allah yang benar-benar menjadi jawaban atas kesesakan yang sedang mereka hadapi. Kuasa dan kemampuan untuk menghadapi ketidakpastian dan kesengsaraan hidup ini hanya terdapat di dalam Allah. "Tempat perlindungan" menggambarkan perlindungan dari bahaya, menunjukkan bahwa Allah adalah keamanan sejati di tengah-tengah badai kehidupan (Yes 4:5-6). "Kekuatan" mengacu kepada keperkasaanNya ketika memerangi musuhmusuh (Maz 21:9; Kel 15:13) dan mencakup kekuatan-Nya yang bekerja dengan kuat kuasa di dalam orang yang percaya (Kol. 1:29) dan memungkinkan mengatasi halangan-halangan dalam hidup ini. Jadi, Hasil terakhir ialah bahwa Dia menjadi "penolong dalam kesesakan (yang) sangat terbukti". Allah siap sedia untuk

\footnotetext{
${ }^{14}$ Owens, Analytical Key to the Old Testament, 337. [Terjemahan Langsung]

${ }^{15}$ Francis Brown, The Brown Driver Briggs

Hebrew and English Lexicon (Massachusetts:

Hendrikcson Publisher, Inc, 1996), 899.
}

menolong umat-Nya dan mengharapkan berseru kepadaNya memohon pertolongan setiap kali memerlukannya (Ibr 4:16).

\section{Pertolongan Allah yang Bersifat Praktis}

Dalam memberikan pembahasan yang bersifat praktis penulis memfokuskan pada dua literatur, yang pertama tentu saja diambil dari dalam Mazmur pasal 46, literatur ini akan menjadi sumber studi terhadap topik yang sedang dibahas dalam bagian ini.

1. Penyertaan Allah Kepada UmatNya (Ay. 5-8)

Dalam ayat 5 muncul ungkapan "kediaman" merupakan terjemahan terhadap bahasa Ibrani kedos mesekeni yang diterjemahkan tempat kediaman kudus. ${ }^{14}$ ungkapan tersebut tentunya menunjuk pada Yerusalem yang merupakan kota Allah, tempat eksistensi Allah dalam bait suciNya. Bagian tersebut menunjukkan bahwa Yerusalem sebagai kota suci pasti akan terlindungi karena Allah ada didalamnya.

Penyertaan Allah yang sekaligus merupakan bukti dari pertolongan Allah yang bersifat praktis, dapat ditemukan dalam istilah ada didalamnya (Mzm. 46:6). Ungkapan tersebut merupakan terjemahan terhadap kata Ibrani HB'r>qiB.â (beqirebah). Istilah tersebut berasal dari kata benda qereb yang berarti berada di bagian dalam. ${ }^{15}$ Hal ini memberikan indikasi bahwa kehadiran Allah nyata dalam eksistensinya ditengah-tengah Yerusalem, membawa pada suatu pengertian bahwa Allah hadir dan memiliki penguasaan langsung yang efektif ataus seluruh dunia. ${ }^{16}$ Kehadiran Allah dalam kota memberikan kedamaian seperti sungai yang tidak pernah berhenti mengalir, sangat kontras dengan tempat lain dimana Allah tidak ada didalamnya, seperti yang digambarkan dalam Yesaya 8:6; 33:21. 17 "Sungai" ini adalah kiasan untuk hadirat Allah (ay.6). Sungai ini tidak menakutkan, melainkan menyukakan. Kebalikan dari akibat air laut dalam ay.3-4, sungai ini membuat kota Allah (Yerusalem)

\footnotetext{
${ }^{16}$ Leslie S. M'Caw; J.A. Motyer "Mazmur," dalam Tafsiran Alkitab Masa Kini 2, pen., F. Ukur (Jakarta: Yayasan Komunikasi Bina Kasih/OMF, 2012), 177. ${ }^{17}$ Walvoord, The Bible Knowledge, 828.
} 
tidak goncang. "Sungai" Allah merupakan aliran yang terus-menerus dari kasih karunia, kemuliaan, dan kuasa-Nya di tengah-tengah umat-Nya yang setia (Mzm 46:12; Yes 8:6; Yeh 47:1; Why 3:12; 22:1). Sungai jernih yang memberi hidup ini mengalir dari Allah Bapa (Yer 2:13), Allah Anak (Yoh 4:14) dan Allah Roh Kudus (Yoh 7:38-39); sungai ini mengalir dari takhta Allah dan tak henti-hentinya menyegarkan orang percaya, baik mereka yang ada di bumi (Yoh 4:13-14; 7:38) maupun mereka di sorga (Why. 22:1). Berkat yang paling penting dari sungai ini adalah bahwa olehnya Allah dibawa di tengah-tengah umat-Nya (ay. 6). Ayat 7 bangsa-bangsa dan kerajaan-kerajaan menjelaskan tentang gelora politik. Air bah dalam ayat 3-4 adalah kiasan untuk gelora politik tetapi ada pertolongan Allah digambarkan dengan dahsyat dalam ayat 7b: Dia berfirman dan bumi yaitu bangsabangsa yang bergelora akibatnya bumi pun hancur. Ayat 8 menjelaskan bahwa Allah alam semesta dalam Ibrani hl's,( bqoå[]y: yang dijunjung tinggi sebagai perlindungan ialah Allah, bukan tembok-tembok kota Yerusalem.

2. Perlindungan Allah atas umatNya (Ay. 9-12)

Dalam bagian ini pemazmur mengajak umat merenungkan sejarah 'kemenangan' Allah melawan segala kuasa di bumi. Bahwa tidak ada satu kuasa pun di bumi yang tidak tunduk pada kuasa Allah. Kesimpulan dari krisis itu harus jelas bagi segala bangsa. Wahyu 8:1 "ketika untuk sementara ada penghentian dari perang dan penganiayaan; dan seperti yang akan terjadi di zaman akhir, dan yang di sini terutama dirancang; ketika bangsa-bangsa akan belajar perang lagi, dan kerajaan Kristus akan terjadi; yang dan kedamaiannya tidak akan ada akhirnya, Yesaya 2: 4. Kehidupan yang dibawah pikiran yang tertekan di bawah ketakutan yang mengerikan akan kesulitan yang ada saat ini dan malapetaka publik yang akan terjadi ada penghibiran Allah tentang masa depan.

Istilah Ibrani "diamlah" dalam ayat 11 juga dapat diterjemahkan dengan "lepaskanlah", yaitu berhentilah memegang halhal yang menghalangi meninggikan Allah dan memberikan Dia tempatNya yang layak karena Tuhan itu Allah. Diamlah, dan ketahuilah bahwa Akulah Allah! Kata-kata ini dianggap oleh beberapa orang untuk diucapkan oleh Tuhan kepada bangsa-bangsa di dunia, untuk "berhenti dari perang", karena Allah adalah Allah, dan memiliki kekuatan untuk membangkitkan dan membuat rendah; Dan mengetahui"; memiliki dan mengakui bahwa ia adalah Tuhan, sebagai wujud kedaulatannya melakukan apa pun yang diinginkannya; bahwa dia tidak dapat diubah dalam sifat, tujuan, janji, dan perjanjiannya; bahwa ia mahakuasa, mampu membantu mereka dan mengantarkan mereka pada ekstremitas terakhir; bahwa dia mahatahu, tahu orang-orang, kasus, dan masalah, dan bagaimana dan di mana menyembunyikan atau melindungi mereka sampai badai selesai; bahwa dia adalah Allah yang Maha Bijaksana, dan melakukan segala sesuatu menurut nasihat kehendaknya sendiri, dan membuat segala sesuatu bekerja bersama demi kebaikan bagi mereka; dan bahwa dia setia pada janji dan janji-Nya, dan tidak akan membiarkan mereka terlalu ditekan dan diliputi masalah.

Jadi, Allah menghentikan peperangan sampai ujung bumi, kemudian menghancurkan segala peralatan dengan mematahkan busur panah, menumpulkan tombak, membakar kereta-kereta perang. Ini adalah npenghancuran semua senjata dan gerbong militer ini adalah tanda perdamaian, dan perang yang disebabkan untuk berhenti, tidak ada gunanya lagi bagi mereka; dengan ini membandingkan Yehezkiel 39:8.

Ayat 12 perhatikan, ayat 8 dan 12 mempunyai penjelasan yang menarik tentang penyebutan Tuhan semesta alam yang juga Allah Yakub sebagai gelar perjanjian akan menyertai yang berarti Imanuel. Kata-kata yang sama di sini diulang, untuk menghibur mereka yang takut dan tidak percaya, yang dengannya gereja kemudian menghibur dirinya sendiri.

\section{KESIMPULAN}

Tinjauan teologi dalam mazmur 46:112 menjelaskan dua aspek yang pertama Pertolongan Allah Secara Teologis yaitu Allah sebagai tempat perlindungan dan Allah sebagai keselamatan, memberi kesaksian tentang 
keandalan Allah, dan pertolongan Allah secara praktis yaitu ayat 9-11 mengajak pendengar untuk merenungkan kesaksian itu yaitu Allah menyertai umatNya dan Allah adalah tempat perlindungan dan sumber penyegaran di tengah kesesakan, dan Dia juga bermaksud untuk menghapus segala kekacauan dalam dunia politik manusia (ayat 10) supaya seluruh bumi meninggikan Dia..

\section{DAFTAR PUSTAKA}

Hassell Bullock, Kitab-kitab Puisi dalam Perjanjian Lama, pen., Suhadi Yeremia, peny., Sumarah (Malang: Gandum Mas, 2003), 152.

Henry C. Thiessen, Teologi Sistematika (Malang: Yayasan Penerbit Gandum Mas, 1997), 118, 134-135.

Leslie S M'Caw, “Mazmur” dalam Tafsiran Alkitab Masa Kini 2, pen., F. Ukur Jakarta: Yayasan Komunikasi Bina Kasih, 1996), 177.

Walter C. Kaiser, Teologi Perjanjian Lama (Malang: Gandum Mas, 2000), 133.

Alec Motyer, "Nama-nama Sebutan untuk Allah" dalam Pedoman Lwngkap Pendalaman Alkitab, 1978.

John F. Walvoord, The Bible Knowledge Commentary (Grand Rapids: Victor Book, 1995), 825.

Jhon Joseph Owens, Analitical Key to the Old Testament (Grand Rapids: Baker Book House, 1995), 336.

William Dyrness, Tema-tema dalam Teologi Perjanjian Lama, 30.

Owen, Analitical Key

John F. Walvoord, The Bible Knowledge Cpmmentary, 228.

Owens, Analytical Key to the Old Testament, 337.

Francis Brown, The Brown Driver Briggs Hebrew and English Lexicon (Massachusetts: Hendrikcson Publisher, Inc, 1996), 899.

Leslie S. M'Caw; J.A. Motyer "Mazmur," dalam Tafsiran Alkitab Masa Kini 2, pen., F. Ukur (Jakarta: Yayasan Komunikasi Bina Kasih/OMF, 2012), 177. 